\title{
STRUKTUR DAN VARIABILITAS ARLINDO DI LAUT SULAWESI
}

\author{
STRUCTURE AND VARIABILITY OF INDONESIAN THROUGHFLOW \\ AT SULAWESI SEA
}

\author{
Agus S. Atmadipoera ${ }^{1)}$ dan Galang L. Mubaraq ${ }^{2)}$ \\ ${ }^{1)}$ Lab. Oseanografi Fisika, Dept. ITK, FPIK IPB Bogor \\ ${ }^{2)}$ Program Studi Ilmu dan Teknologi Kelautan (ITK), FPIK IPB Bogor \\ email: atmadipoera_itk@ipb.ac.id
}

Diterima tanggal : 2 November 2016, diterima setelah perbaikan : 27 Januari 2017, disetujui tanggal 16 Februari 2017

\begin{abstract}
ABSTRAK
Laut Sulawesi (SUL) merupakan gerbang utama masuknya Arus Lintas Indonesia (Arlindo), yang membawa sekitar 15 Sv massa air hangat dan asin dari Samudera Pasifik menuju Samudera Hindia. Sirkulasi dan variabilitas arus di basin SUL masih belum dipahami dengan baik. Penelitian ini bertujuan untuk mengkaji pola sirkulasi, struktur vertikal arus, dan variabilitas Arlindo SUL pada tiga level kedalaman berbeda (15 m, $130 \mathrm{~m}$, dan $318 \mathrm{~m})$ yang mewakili lapisan tercampur, termoklin dan bawah-termoklin. Keluaran model (2007-2012) dari model sirkulasi laut umum dengan konfigurasi INDESO digunakan untuk analisis data deret-waktu dalam penelitian ini. Hasil penelitian menunjukkan bahwa pola sirkulasi di SUL dicirikan dengan tiga wilayah arus yang unik: (a) poros utama aliran Arlindo dengan vektor arus yang kuat di sepanjang lintasannya, (b) sirkulasi siklonik di bagian selatan basin SUL, dan (c) sirkulasi antisiklonik di bagian utara basin. Struktur vertikal arus terungkap bahwa aliran Arlindo mengalami intensifikasi di kedalaman antara $150 \mathrm{~m}$ dan $250 \mathrm{~m}$ dengan kecepatan maksimum sekitar $60 \mathrm{~cm} /$. Analisis power spectra density menunjukkan bahwa variabilitas arus di SUL didominasi oleh periodisitas skala intra-musiman dengan puncak spektral energi pada periodisitas antara 21 dan 59 hari. Variabilitas skala-waktu ini diduga kuat terkait dengan signal kedatangan gelombang Rossby dari sistem arus tepi batas barat ekuator Pasifik. Koherensi yang signifikan antara fluktuasi arus di lokasi inflow dan outflow, serta di basin SUL, terjadi di sepanjang sumbu utama Arlindo dengan beda fase antara 15 dan 31 hari.
\end{abstract}

Kata Kunci: Laut Sulawesi, Arus Lintas Indonesia (Arlindo), INDESO, struktur vertikal arus, analisis power spectra density, variabilitas arus skala intra-musiman.

\begin{abstract}
Sulawesi Sea (SUL) is the main inflow gate of the Indonesian Throughflow (ITF), which transfers 15 Sv of warmer and saltier water masses from the Pacific Ocean into the Indian Ocean. Circulation in SUL basin is still not well understood. This research aims to investigate circulation pattern, vertical current structure, variability of current in three depth levels $(15 \mathrm{~m}, 130 \mathrm{~m}$, and $318 \mathrm{~m})$, representing mixed layer, thermocline and below-thermocline layers. Model outputs (2007-2012) from the INDESO configuration of ocean general circulation model was used for timeseries data analysis in this study. The results show that circulation pattern in SUL is indicated by three distinct regimes: (a) main axis of ITF flow along its pathway with much stronger current vector fields, (b) cyclonic circulation in southern part of the basin, and (c) anti-cyclonic circulation in northern basin. Vertical structure of the current revealed that the ITF flow is intensified at depth between $150 \mathrm{~m}$ and $250 \mathrm{~m}$ with its maximum velocity of $60 \mathrm{~cm} / \mathrm{s}$. Power spectra analysis indicates that current variability in SUL is dominated by intra-seasonal time-scales with energy spectral peaks at periodicity between 21 and 59 days, which may be related with the arrival of Rossby waves from western boundary current system in the equatorial Pacific. Significant coherency between current at the inflow and outflow, as well as, in the SUL basin, appears along the ITF main axis with phase lags between 15 and 31 days.
\end{abstract}

Keywords: Sulawesi Sea, Indonesian Throughflow, INDESO, vertical current structure, power spectra density analysis, intra-seasonal variability. 


\section{PENDAHULUAN}

Laut Sulawesi termasuk sebagai salah satu pintu utama masuknya Arus Lintas Indonesia (Arlindo) dari Samudra Pasifik menuju Hindia, yang melintasi perairan Indonesia dengan volume transpor sekitar $11 \times 10^{6} \mathrm{~m}^{3} \mathrm{~s}^{-1}$ (Gordon et al. 1999; 2010). Arlindo merupakan perpanjangan (ekstensi) dari sebagian jet Arus Mindanao (MC) yang bersumber dari Arus Ekuator Utara (Gambar 1). Arlindo yang memasuki Laut Sulawesi sebagian besar mengalir ke Selat Makassar dan sisanya mengalir kembali ke Samudra Pasifik sebagai bagian dari Arus Balik Ekuator Utara (NECC) (Fine et al. 1994). Arlindo memiliki pengaruh besar dalam transportasi massa air di Laut Sulawesi, khususnya pada lapisan permukaan hingga lapisan termoklin (Sprintall et al. 2009). Arlindo merupakan cabang arus dari sirkuluasi arus termohalin global, yang membawa massa air hangat di lapisan termoklin (Gordon 1986).

Fenomena pergerakan massa air yang terjadi sepanjang tahun di perairan Indonesia, salah satunya bagiannya yaitu Laut Sulawesi akan mengakibatkan terjadinya variabilitas parameter oseanografi baik suhu, salinitas, maupun arus (Gordon 2005). Variabilitas tersebut dapat terjadi dalam periode fluktuasi intra-musiman (intra-seasonal), musiman (seasonal), tahunan (annual), dan antartahunan (inter-annual), yang dapat diketahui melalui analisis data deret waktu. Penelitian Qiu et al. (1999) di Laut Sulawesi menunjukkan adanya variasi intra-musiman pada skala 50 harian akibat dari rambatan gelombang Rossby dan eddy siklonik Mindanao. Sinyal fluktuasi arus tersebut dapat mencapai Selat Makassar dan Laut Banda (Qiu et al. 1999, Susanto et al. 2000).

Studi tentang struktur dan variabilitas arus di Laut Sulawesi menjadi penting karena pengukuran arus secara langsung di wilayah studi masih jarang dilakukan sehingga penelitian arus menggunakan hasil model sirkulasi merupakan komplemen dari pengukuran secara langsung untuk memahami fenomena arus dalam skala ruang dan waktu yang luas yang bermanfaat untuk menjelaskan pola pertukaran massa air yang dibawa dari Pasifik Utara bagian barat menuju perairan Indonesia. Selain itu pengkajian arus dapat dimanfaatkan sebagai informasi umum untuk pelayaran dan perikanan di Laut Sulawesi.

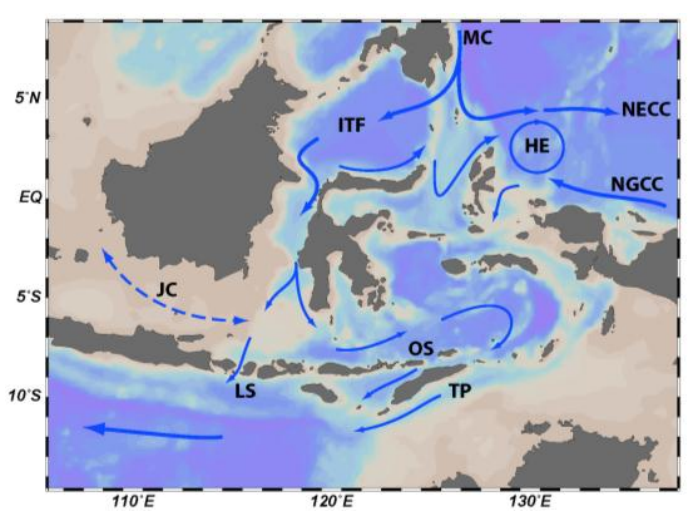

Gambar 1 Skema sirkulasi arus di wilayah studi, dan barat ekuator Samudera Pasifik

(dimodifikasi dari Fine et al. 1994; Atmadipoera et al. 2015).

Salah satu sistem pemodelan sirkulasi laut adalah model Nucleus for European Modeling of the Ocean (NEMO), yang menggunakan persamaan primitif 3-dimensi dalam skala global (Madec, 2008). Sistem grid horisontal untuk distribusi variabel model menggunakan jenis grid Arakawa (grid C), dimana variabel kecepatan arus zonal ditempatkan pada sisi grid timur/barat, variabel kecepatan arus meridional pada sisi utara/selatan, serta variabel skalar (suhu, salinitas, densitas, tinggi muka laut) ditempatkan di tengah grid. Grid vertikal model NEMO menggunakan 50 step $z$-coordinate dengan resolusi lebih tinggi di bagian permukaan. Program pemodelan oseanografi INDESO (Infrastructure Development for Space Oceanography) di wilayah laut Indonesia dan sekitarnya menggunakan sistem NEMO (CLS 2015, Tranchant et al. 2015).

Penelitian struktur dan variabilitas parameter oseanografi di Laut Sulawesi diperlukan untuk memahami karakteristik sirkulasi laut dan variabilitas arus di wilayah studi. Penelitian ini diharapkan dapat menjawab beberapa pertanyaan berikut :

a) Bagaimana pola sirkulasi laut di tiga lapisan kedalaman berbeda (lapisan 
tercampur, termoklin, dan bawah termoklin), serta pola struktur menegak arus di Laut Sulawesi ?

b) Bagaimana variabilitas arus di lokasi arus-masuk (inflow) dan arus-keluar (outflow) di Laut Sulawesi ? serta bagaimana koherensi antara arus di kedua lokasi tersebut?

Pertanyaan tersebut diharapkan dapat terjawab dengan melakukan analisis dan interpretasi data deret-waktu dari arus laut keluaran model sirkulasi laut INDESO antara 2007 sampai 2012.

\section{BAHAN DAN METODE}

\section{Lokasi dan Waktu Penelitian}

Penelitian ini dilakukan pada bulan Oktober 2014 sampai April 2015 dengan domain model berada di Laut Sulawesi dengan batasan koordinat $1^{\circ} \mathrm{LS}-6^{\circ} \mathrm{LU}$ dan $118-127^{\circ} \mathrm{BT}$ (Gambar 2). Untuk keperluan validasi data anomali tinggi muka laut (SSHA) dan anomali suhu permukaan laut (SSTA) antara hasil model dengan data observasi dari satelit, maka dibuatkan sampling box di sekitar tengah basin Laut Sulawesi. Nilai di dalam kotak tersebut dibuat rataan spasial, sehingga diperoleh data deret-waktunya. Lebih lanjut, untuk analisis dua deret-waktu dari arus di lokasi inflow dan outflow Arlindo yang melintasi Laut Sulawesi, maka dibuatkan sampling box di lokasi inflow $\left(125.5^{\circ} \mathrm{E}\right.$ dan $\left.5^{\circ} \mathrm{N}\right)$ dan outflow $\left(119.25^{\circ} \mathrm{E}\right.$ dan $\left.1^{\circ} \mathrm{N}\right)($ Gambar 2).

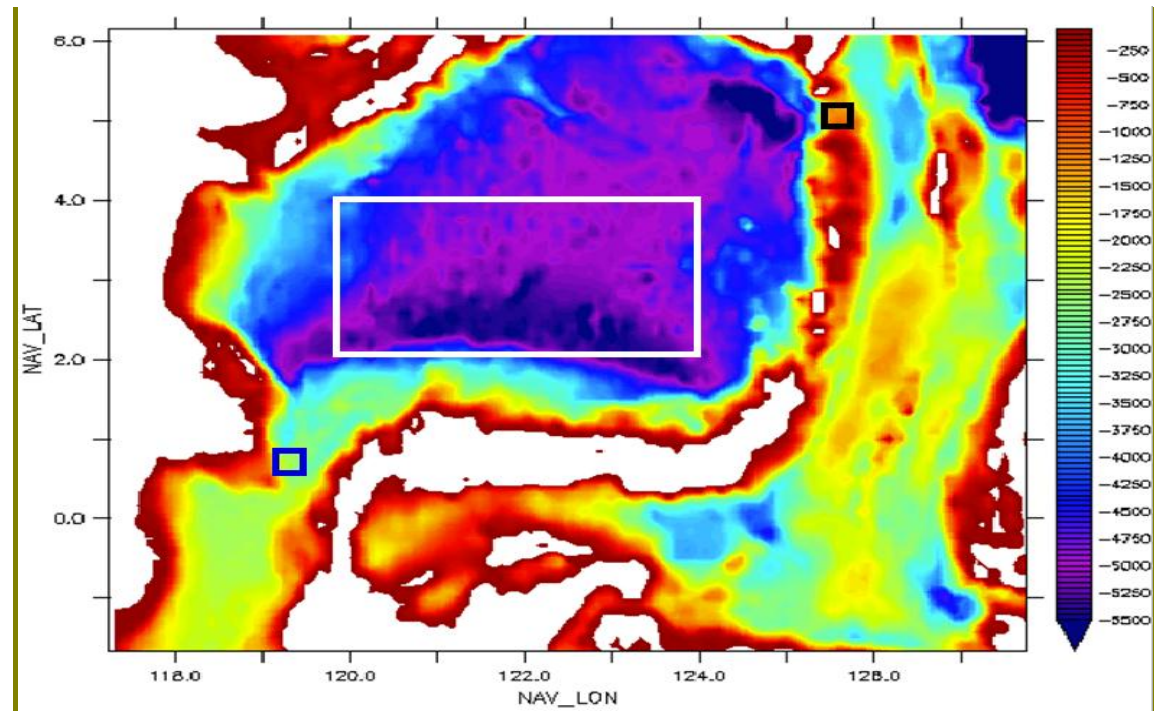

Gambar 2 Batimetri di wilayah studi di Laut Sulawesi dan sekitarnya dari data ETOPO02.

Kotak besar berwarna putih menunjukkan sampling box untuk validasi data SSHA dan SSTA antara keluaran model dan data satelit. Kotak kecil berwarna hitam menunjukkan sampling box untuk komponen arus zonal di lokasi inflow, dan kotak kecil berwarna biru adalah sampling box untuk komponen arus meridional di lokasi outflow sisi utara Selat Makassar.

\section{Data dan Sumber Data}

Data yang digunakan untuk penelitian ini berupa keluaran model sirkulasi 3-dimensi dari INDESO dengan variabel komponen arus zonal, meridional, suhu, salinitas, dan tinggi muka laut (SSH). Rentang data deret waktu dari 3 Januari 2007 sampai 1 November 2012 (5 tahun) (Tranchant et al. 2015). Untuk validasi keluaran model INDESO, digunakan data observasi SSH dan SST dari satelit dalam rentang waktu yang sama (5 tahun). Data model arus merupakan hasil simulasi dengan rataan harian dari model sirkulasi laut yang dikembangkan oleh program INDESO dari

Balai Penelitian dan Observasi Laut, Kementerian Kelautan dan Perikanan (BPOL KKP). Data model arus berupa data grid yang memiliki resolusi horizontal $1 / 12^{\circ}$ atau sekitar $9.25 \mathrm{~km}$ dan resolusi vertikal terdiri dari 50 
level kedalaman. Data arus yang ada di Laut Sulawesi mencapai 49 level kedalaman karena batimetri model di wilayah studi mencapai kedalaman sekitar $5500 \mathrm{~m}$.

Data pengukuran arus secara langsung di wilayah studi belum tersedia, sehingga validasi data digunakan data anomali SSH dan SPL. Validasi model anomali SSH dilakukan dengan data anomali SSH dari AVISO (Archiving, Validation and Interpretation of Satellite Oceanographic data) yang berasal dari kombinasi satelit multi-sensor satelit altimetri Jason-1, TOPEX/Poseidon, Geodetic Satellite (GEOSAT), Environmental Satellite (ENVISAT), Geosat Follow-On (GFO), dan European Remote Sensing (ERS 1/2). Data dapat diakses melalui http://motu.aviso.altimetry.fr. Data tersebut memiliki resolusi spasial sebesar $1 / 4^{\circ}$ atau $27.78 \mathrm{~km}$ dan resolusi temporal 8 harian dengan data rataan anomali pada tahun 1993 hingga 2012.

Validasi model SPL dilakukan dengan data suhu yang berasal dari satelit NOAA AVHRR resolusi-tinggi data suhu permukaan laut. Data dapat diakses melalui https://www.esrl.noaa.gov/psd/cgi-

bin/DataAccess. dengan resolusi spasial sebesar $1 / 24^{\circ}$ atau $4.63 \mathrm{~km}$ dan resolusi temporal 1 harian.

\section{Pengolahan dan Analisis Data}

Langkah awal pengolahan data adalah validasi model yang bertujuan mengetahui tingkat keakuratan model terhadap data dari hasil citra satelit berdasarkan nilai korelasinya. Data arus pengukuran langsung tidak ada sehingga digunakan data anomali tinggi muka laut dan suhu permukaan laut untuk proses validasi data model yang diharapkan apabila hasil validasi baik maka data lain yang terdapat pada model juga baik. Validasi data menggunakan persamaan koefisien korelasi (Emery dan Thomson 2014). Skema diagram alir pengolahan dan analisis data dalam penelitian ini disajikan pada Gambar 3.

Struktur menegak komponen arus ditampilkan dalam bentuk rataan profil menegak dan standar deviasi kecepatan arus pada dua titik sampling, yaitu di lokasi inflow pada koordinat $125^{\circ} 15^{\prime} \mathrm{BT}$ dan $5^{\circ} \mathrm{LU}$ serta di lokasi outflow pada koordinat $119^{\circ} 15^{\prime} \mathrm{BT}$ dan $0^{\circ} 45^{\prime} \mathrm{LU}$. Metode ini bertujuan menampilkan profil menegak kecepatan komponen arus rata-rata (zonal dan meridional) terhadap selang waktu sehingga dapat ditentukan komponen arus yang lebih mendominasi pada kedua titik pengamatan tersebut.

Analisis data deret-waktu dengan densitas spektral energi (power spectral density, PSD) bertujuan untuk menganalisis periodisitas dari data deret-waktu arus, sehingga bisa diamati puncak-puncak energi fluktuasi arus pada periode atau frekuensi tertentu. Hasil analisis PSD dapat ditemukan satu atau lebih puncakpuncak densitas energi arus dengan nilai energi yang dominan, disebut sebagai puncak energi spektral. Metode Fast Fourier Transform (FFT) merupakan metode yang digunakan untuk mengestimasi nilai PSD dengan cara mencari nilai komponen Fourier $\left(X\left(f_{k}\right)\right)$ dari deret waktu $x_{n}$ pada selang waktu $\Delta t$ (1 hari) dengan persamaan (Bendat dan Piersol 2010):

$$
X\left(f_{k}\right)=\Delta t \sum_{t=0}^{N-1} x_{n} \exp \left[-j \frac{2 \pi k n}{N}\right]
$$

dimana :

$X\left(f_{k}\right)=$ Komponen Fourier

$\Delta t=$ Selang waktu data

$k=0,1,2, \ldots, N-1$

$N=$ jumlah data

Nilai PSD dihitung dengan persamaan (Bendat dan Piersol 2010):

$$
S_{x}=\frac{2 \Delta t}{N}\left|X\left(f_{k}\right)\right|^{2}
$$

Dengan:

$S_{X}=$ Nilai PSD

Agar dapat dihitung level signifikan maka perlu dilakukan pemotongan data. Panjang data 2082 dipotong 512 data pada setiap segmen membentuk 4 segmen. Kemudian hasil PSD dari 4 segmen tersebut dihitung nilai level signifikan pada selang kepercayaan $95 \%$. 
Bila puncak energi PSD lebih tinggi dari tinggi pita level signifikan maka secara statistik dinyatakan sebagai puncak spektrum densitas energi signifikan (Emery dan Thomson 2014):

$$
\bar{x}-Z \alpha / 2\left(\frac{S}{\sqrt{N}}\right)<\mu<\bar{x}+Z \alpha / 2\left(\frac{S}{\sqrt{N}}\right)
$$

dengan:

$\mu=$ Level signifikan

$\bar{x}=$ Rata-rata spektrum densitas energi

$Z \alpha / 2=$ Standarisasi sebaran normal pada

selang kepercayaan $\alpha$

$S=$ Simpangan baku

$N=$ Jumlah data

Analisis koherensi digunakan untuk menganalisis hubungan antara fluktuasi dua atau lebih variabel. Analisis koherensi dilakukan antara komponen arus dominan pada inflow dengan komponen arus dominan pada outflow di tiga lapisan kedalaman (tercampur 15m, termoklin 130m, bawah termoklin $318 \mathrm{~m})$. Analisis koherensi terdiri dari kospektral energi, koherensi dan beda fase.

Kospektral energi menunjukkan besarnya energi fluktuasi pada periode yang sama antara kedua variabel. Apabila terjadi fluktuasi arus di lokasi inflow dan signal arus tersebut merambat ke lokasi outflow, maka dapat dikatakan keduanya akan menunjukkan koherensi (hubungan) yang kuat antara kedua variabel (nilai koherensi yang tinggi). Beda fase menunjukkan perbedaan selang waktu antara kedua variabel. Beda fase positif menunjukkan bahwa fluktuasi variabel yang mempengaruhi mendahului variabel yang dipengaruhi, sedangkan beda fase negatif menunjukkan bahwa fluktuasi variabel yang dipengaruhi mendahului variabel yang mempengaruhi.

Kospektral energi $\left(G_{x y}\left(f_{k}\right)\right)$ dihitung dari dua pasang komponen Fourier dari data deret waktu $x_{n}$ dan $y_{n}$ yang diukur dalam setiap selang waktu $\Delta t$ dengan menggunakan rumus (Bendat dan Piersol 2010):

$$
G_{x y}\left(f_{k}\right)=\frac{2 \Delta t}{T}\left|X\left(f_{k}\right) * Y\left(f_{k}\right)\right|
$$

Dengan:

$X\left(f_{k}\right)=$ Komponen Fourier dari $x_{n}$ $Y\left(f_{k}\right)=$ Komponen Fourier dari $y_{n}$ $T \quad=$ Periode data

Fungsi koherensi $\left(\gamma_{x y}^{2}\left(f_{k}\right)\right)$ dihitung menggunakan persamaan (Bendat dan Piersol 2010):

$$
\gamma_{x y}^{2}\left(f_{k}\right)=\frac{\left|G_{x y}\left(f_{k}\right)\right|^{2}}{s_{x}\left(f_{k}\right) S_{y}\left(f_{k}\right)}
$$

Dengan:

$S_{x}\left(f_{k}\right)=$ Densitas energi $X\left(f_{k}\right)$

$S_{y}\left(f_{k}\right)=$ Densitas energi $Y\left(f_{k}\right)$

Nilai beda fase $\left(\theta_{x y}\left(f_{k}\right)\right)$ dihitung menggunakan persamaan (Bendat dan Piersol 2010):

$$
\theta_{x y}\left(f_{k}\right)=\tan ^{-1}\left[\frac{Q_{x y}\left(f_{k}\right)}{C_{x y}\left(f_{k}\right)}\right]
$$

Dengan:

$Q_{x y}\left(f_{k}\right)=$ Nilai imajiner dari $G_{x y}\left(f_{k}\right)$

$C_{x y}\left(f_{k}\right)=$ Nilai nyata dari $G_{x y}\left(f_{k}\right)$

Nilai beda fase diubah dalam satuan waktu (hari) menggunakan persamaan:

$$
\begin{aligned}
& \text { Beda fase (hari) }=\frac{\tan ^{-1} \theta_{x y}\left(f_{k}\right)}{360} \times \\
& \text { periode fluktuasi (hari) }
\end{aligned}
$$




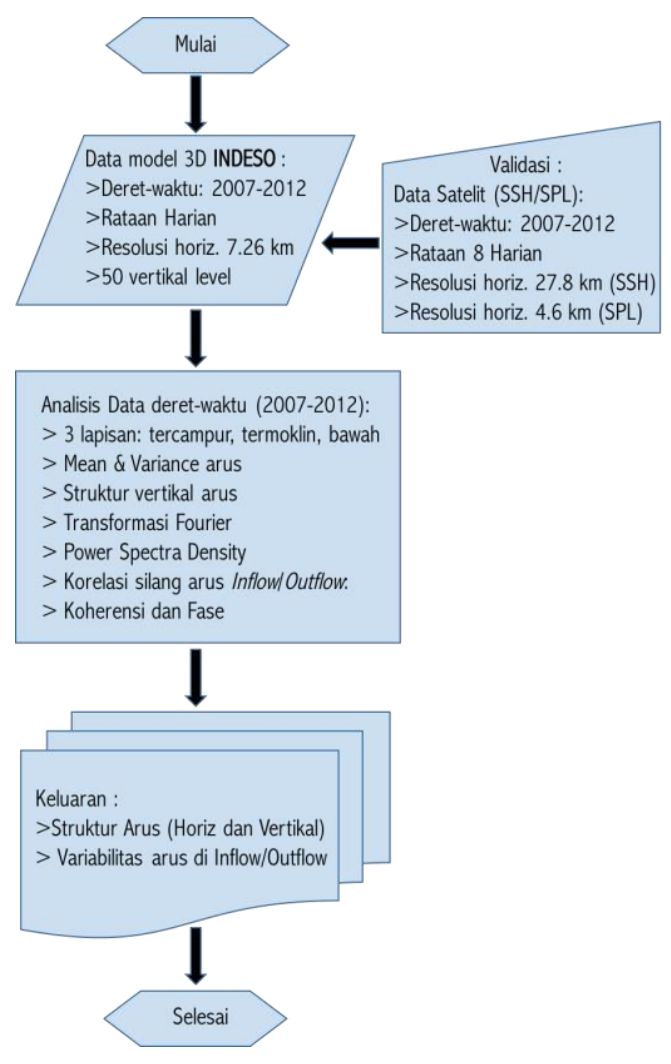

Gambar 3 Diagram alir pengolahan dan analisis data dalam penelitian ini.

\section{Validasi Data Keluaran Model INDESO dan Data Observasi Satelit}

Data keluaran model INDESO untuk variabel anomali tinggi muka laut dan suhu permukaan laut divalidasi dengan menggunakan data dari hasil observasi satelit. Validasi ini dilakukan untuk melihat performa hasil model INDESO. Mengingat tidak tersedia data lapangan untuk arus, maka digunakan variabel anomali tinggi muka laut (SSHA) dan suhu permukaan laut (SPL). Data deret waktu SSHA dan SPL dari satelit dan model dari tahun 2007-2012 ditampilkan pada Gambar 4. Data deret-waktu SSHA (Gambar 4a) terlihat fluktuasinya cukup mirip, dimana fluktuasi tahunan SSHA terlihat negatif dalam tahun pertama (2007) dan cenderung SSHA negatif dalam periode musim timur (Juli-September). Beberapa puncak fluktuasi SSHA frekuensi tinggi, seperti Maret 2008, Januari 2009, dan Januari 2010 yang tercatat di data satelit tidak tergambar secara jelas dari hasil model. Nilai koefisien korelasi dari kedua data tersebut sekitar 0.78, yang menunjukkan tingkat keeratan yang cukup tinggi. Data deret-waktu SPL dari satelit dan model (Gambar 4b) terlihat menunjukkan fluktuasi yang cukup besar. Beberapa puncak SPL dari kedua data terlihat cukup mirip, seperti puncak SPL Mei dan Oktober 2007, Oktober 2008. Selain itu, beberapa SPL minimum dari kedua data juga terlihat mirip, seperti bulan Januari/Februari 2007/2008/2009 dan seterusnya, meskipun amplitudo SPL dari pengukuran satelit lebih tinggi, serta fluktuasi frekuensi tinggi dari data satelit terlihat lebih kuat. Nilai koefisien korelasi antara kedua data tersebut tercatat cukup tinggi sekitar 0.75. Dengan demikian, keluaran model untuk variabel suhu, SSHA dan arus cukup mampu mereproduksi keadaan sebenarnya di alam, sehingga dapat digunakan untuk analisis lebih lanjut untuk keperluan penelitian ini. 

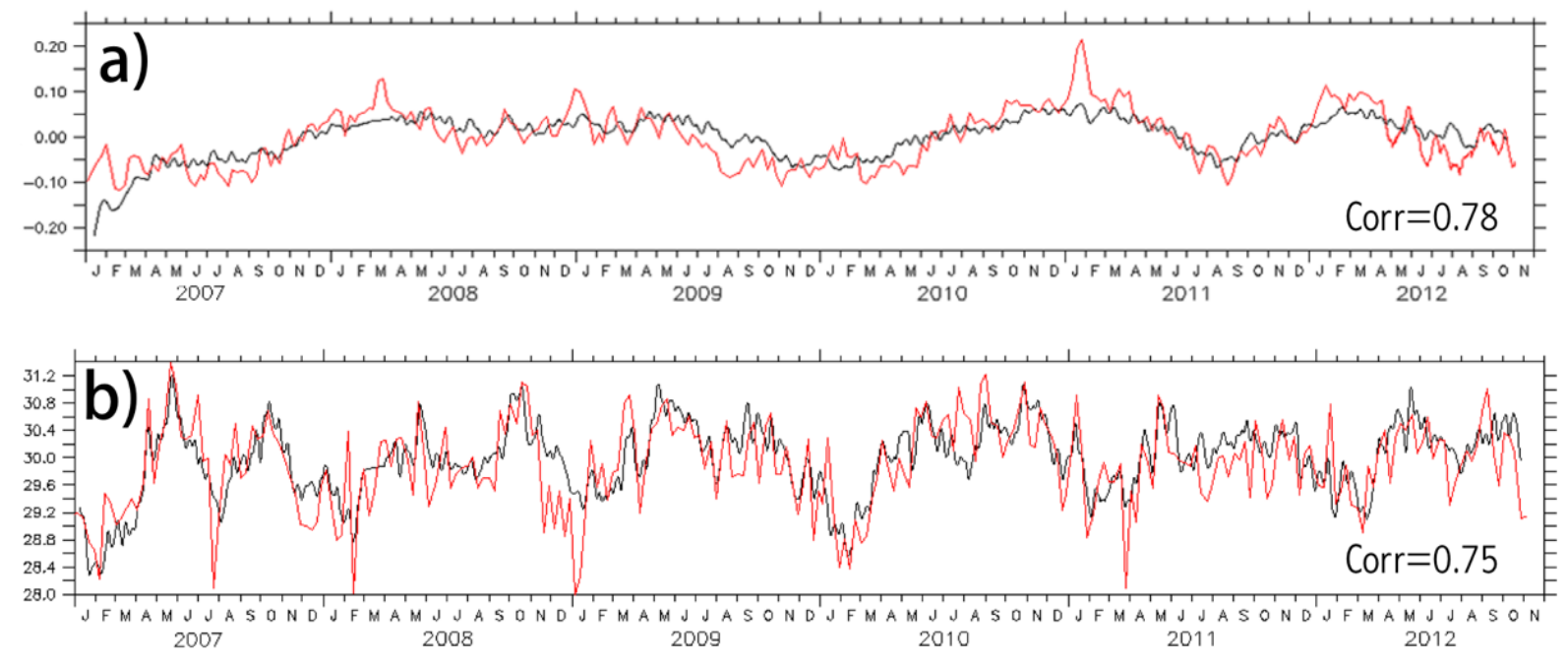

Gambar 4 Korelasi anomali tinggi muka laut dari data satelit altimetri AVISO (merah) dan keluaran model INDESO (hitam) (a); serta korelasi suhu permukaan laut dari data satelit MODIS (merah) dan keluaran INDESO (hitam) (b) pada periode 2007 sampai 201 dari sampling box di Gambar 2. Nilai koefisien korelasi anomali tinggi muka laut adalah 0.78, dan suhu permukaan laut sekitar 0.75.

\section{HASIL DAN PEMBAHASAN}

\section{Pola Sirkulasi Arlindo Sulawesi}

Rerata sirkulasi yang ditampilkan dengan vektor arus di tiga lapisan kedalaman berbeda, yang mewakili lapisan tercampur (kedalaman $15 \mathrm{~m})$, termoklin $(130 \mathrm{~m})$ dan bawah termoklin (318m) ditampilkan pada Gambar 5. Lintasan arus utama dengan vektor arus yang lebih kuat terlihat jelas mengalir dari pintu masukan (inflow) di bagian selatan Tanjung Mindanao ke arah baratdaya dan melintasi bagian tengah Laut Sulawesi, kemudian berlanjut masuk menuju pintu utara Selat Makassar, dan sebagian mengalami resirkulasi. Lintasan arus utama ini adalah representasi sumbu Arus Lintas Indonesia (Arlindo) di Laut Sulawesi. Arus utama yang masuk dari wilayah inflow merupakan cabang dari arus kuat Arus Mindanao yang menjadi pangkal Arlindo. Pada sisi utara dan sisi selatan dari sumbu arus utama Arlindo tersebut, terbentuk resirkulasi arus yang bergerak searah jarum jam (clockwise) dan berlawanan arah jarum jam (anti-clockwise) dan sebagian lain keluar menuju Laut Maluku (Gambar 5). Luasan wilayah resirkulasi arus di sisi utara dari sumbu utama Arlindo terlihat semakin mengecil dengan semakin bertambahnya kedalaman karena sumbu utama Arlindo cenderung bergeser semakin ke arah utara dengan bertambahnya kedalaman. Sebaliknya, luasan resirkulasi di sisi selatan sumbu Arlindo menjadi semakin luas dengan bertambahnya kedalaman. Amplitudo kecepatan arus di lapisan dekat permukaan adalah terbesar, dan semakin melemah ke kedalaman.

Pola sebaran suhu air laut berkaitan erat dengan pola sirkulasi di tiga kedalaman berbeda tersebut. Suhu air laut di lapisan tercampur (Gambar 5a) di wilayah tengah resirkulasi arus sisi utara dan selatan dari sumbu Arlindo menunjukkan suhu yang lebih tinggi dibandingkan suhu di wilayah sumbu arus utama Arlindo dengan gradien horizontal suhu sekitar $1-1.5^{\circ} \mathrm{C}$. Di lapisan termoklin (Gambar 5b) di wilayah resirkulasi utara dan selatan menunjukkan suhu yang lebih rendah dibanding suhu di wilayah arus utama dengan gradien horizontal suhu sekitar $2-2.5^{\circ} \mathrm{C}$. Di lapisan bawah termoklin (Gambar 5c) suhu di wilayah resirkulasi utara terlihat lebih tinggi dibanding dengan suhu di wilayah resirkulasi selatan maupun arus utama Arlindo dengan gradien horizontal suhu sekitar $0.3-1{ }^{\circ} \mathrm{C}$. 

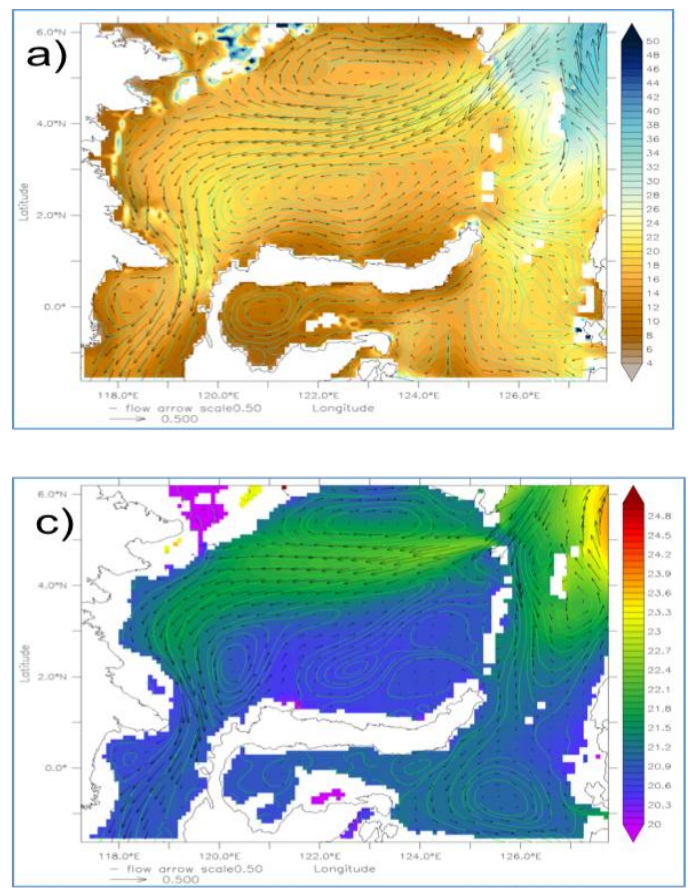
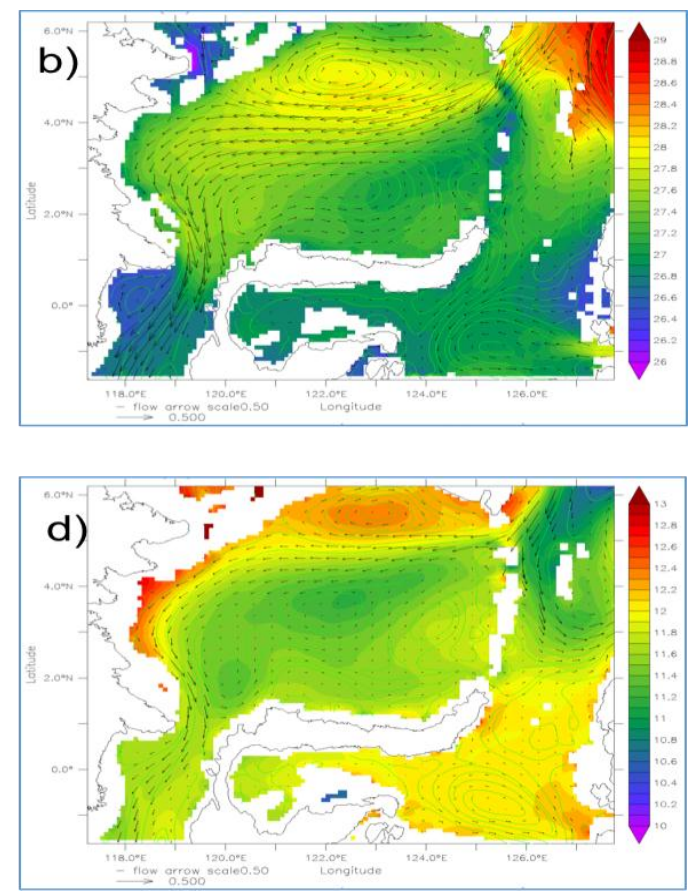

Gambar 5 Rerata vektor arus (2007-2012) yang ditumpang-susunkan dengan (a) kedalaman lapisan tercampur pada lapisan tercampur (10 m); (b) suhu air laut pada batas atas termoklin $(66 \mathrm{~m})$; (c) suhu air laut pada lapisan termoklin (156m): dan (d) suhu air laut pada lapisan bawah termoklin $(318 \mathrm{~m})$. Jalur utama Arlindo ditunjukkan dengan vektor arus yang kuat, resirkulasi arus ditunjukkan dengan vektor arus yang lebih lemah. Skala suhu di setiap level kedalaman dibuat berbeda.

Arlindo yang merupakan sistem arus antarbasin Samudera Pasifik ke Hindia menunjukkan paras laut di sisi Pasifik selalu lebih tinggi dibandingkan paras laut di sisi Hindia, sehingga terbentuk aliran Arlindo (Timmermann et al., 2010; McGregor et al., 2012). Pengaruh komponen gaya Coriolis dapat terjadi pada sirkulasi di Laut Sulawesi, dimana Arlindo yang terbentuk cenderung dibelokan ke arah kanan dari arah alirannya karena Laut Sulawesi berada di Bumi Belahan Utara. Hal ini terlihat dari sumbu utama

Arlindo mendekati pantai utara Kalimantan, kemudian bergerak ke selatan mengikuti kontur batimetri sepanjang lerengan (slope) bagian timurlaut Kalimantan. Sehingga terlihat bahwa Arlindo Sulawesi mengalami penguatan (intensifikasi) arus di sepanjang tepi barat Laut Sulawesi. Gambaran detil dari Arlindo Sulawesi dari hasil model INDESO ini memberikan pemahanan baru keberadaan penguatan arus tepi barat (western current intensification) Arlindo di Laut Sulawesi.
Hasil model ini sejalan dengan hasil observasi arus dengan SADCP dari ekspedisi EWIN 2014 (Tim EWIN, 2014).

Arus utama di Laut Sulawesi secara dominan membawa massa air masuk ke Selat Makassar. Arus utama tersebut merupakan bagian dari Arlindo, yang memiliki pengaruh besar dalam transportasi massa air di Laut Sulawesi, khususnya pada lapisan permukaan hingga lapisan termoklin (Sprintall et al. 2009; Atmadipoera et al. 2015). Suhu air laut di lapisan termoklin yang berada di sumbu utama Arlindo bernilai lebih tinggi daripada suhu di sekitarnya. Hal ini dikarenakan lapisan termoklin Laut Sulawesi merupakan massa air hangat dari sirkulasi arus termohalin global. Massa air hangat yang dibawa dari Samudra Pasifik terlihat jelas pada lapisan termoklin (Gambar 5b). Penelitian yang telah dilakukan Gordon (1986) juga menunjukkan bahwa massa air hangat di Indonesia dibawa melalui Arlindo. Semakin dalam pergerakan arus di Laut Sulawesi, semakin rendah besaran kecepatan arusnya. Hal ini terjadi karena arus 
yang bergerak pada kedalaman yang lebih dalam lebih sedikit terkena pengaruh eksternal yang dapat membangkitkan arus (Stewart 2008).

\section{Struktur Menegak Arlindo Sulawesi}

Profil menegak rata-rata komponen arus zonal dan meridional antara permukaan sampai kedalaman $1500 \mathrm{~m}$ di lokasi inflow dan outflow disajikan pada Gambar 6. Untuk komponen zonal (timur-barat), tanda arus positif berarti ke arah timur dan negatif ke arah barat, sedang kan komponen meridional (utara-selatan) tanda negatif ke arah selatan dan positif ke arah utara. Komponen arus zonal di lokasi inflow (Gambar 6a) dari permukaan hingga kedalaman sekitar $100 \mathrm{~m}$ terlihat modulus kecepatannya semakin lemah dengan bertambah kedalaman. Kemudian, kecepatannya mencapai maksimal di kedalaman antara $150 \mathrm{~m}$ sampai sekitar $250 \mathrm{~m}$. Lapisan dimana kecepatan maksimum ini merupakan lapisan inti dari Arlindo Makassar. Di bawah lapisan utama Arlindo, kecepatan menurun dengan semakin bertambahnya kedalaman. Modulus rerata komponen arus meridional di lokasi inflow (Gambar 6b) terlihat relatif lemah dibanding dengan komponen arus zonal (Gambar 6a). Kecepatan arus menurun dengan semakin bertambahnya kedalaman dan terlihat relatif seragam modulus kecepatannya di bawah kedalaman $450 \mathrm{~m}$. Dengan demikian, di lokasi inflow, komponen arus zonal menjadi dominan karena konfigurasi pintu masuk Arlindo di timurlaut Laut Sulawesi berorientasi hampir timur-barat.

Berbeda dengan di lokasi inflow, komponen arus di lokasi outflow di bagian utara Selat Makassar (Gambar 6cd), komponen arus meridional menjadi dominan. Kedua komponen arus tersebut dari permukaan hingga kedalaman sekitar $100 \mathrm{~m}$ mengalami peningkatan kecepatan arusnya, kemudian menurun hingga kedalaman $450 \mathrm{~m}$. Lapisan utama Arlindo dengan kecepatan maksimum di lokasi outflow terlihat jelas berada di lapisan sekitar $65 \mathrm{~m}$. Simpangan baku pada kedua komponen arus (zonal dan meridional) di lokasi inflow maupun outflow cenderung besar pada wilayah dekat permukaan, yang diduga berkaitan dengan pengaruh forcing atmosfer di lapisan batas laut-atmosfer.

Bila dibandingkan struktur menegak arus di lokasi inflow dan outflow, terlihat bahwa komponen arus zonal menjadi dominan di lokasi inflow, tetapi komponen arus meridional di lokasi outflow. Hal yang menarik lainnya adalah kedalaman lapisan utama Arlindo di lokasi inflow berada lebih dalam dan lebih tebal antara kedalaman 150-250 m) dengan modulus kecepatan yang relatif seragam $(>0.5$ $\mathrm{m} / \mathrm{s}$ ), tetapi di lokasi outflow lokasi arus utamanya menjadi lebih dangkal dan lebih tipis (sekitar kedalaman 65m) dengan kecepatan $>0.5 \mathrm{~m} / \mathrm{s}$ (Gambar 6).

Secara rinci, rerata kecepatan maksimal komponen zonal di inflow berada pada kedalaman $186 \mathrm{~m}$, yaitu $0.5746 \mathrm{~m} / \mathrm{s}$ ke arah barat serta kecepatan rata-rata tertinggi komponen meridional inflow berada pada kedalaman $0.5 \mathrm{~m}$, yaitu $0.3000 \mathrm{~m} / \mathrm{s}$ ke arah selatan (Gambar 6ab). Hal ini menunjukkan bahwa di wilayah inflow komponen zonal lebih kuat pengaruhnya terhadap pergerakan massa air dibanding komponen meridionalnya. Rerata kecepatan maksimal komponen zonal di lokasi outflow berada pada kedalaman $77 \mathrm{~m}$, yaitu $0.1835 \mathrm{~m} / \mathrm{s}$ ke arah barat serta kecepatan rata-rata tertinggi komponen meridional outflow berada pada kedalaman $65 \mathrm{~m}$, yaitu $0.6004 \mathrm{~m} / \mathrm{s}$ ke arah selatan. Hal ini menunjukkan bahwa di outflow komponen meridional lebih berpengaruh terhadap pergerakan massa air dibanding komponen zonalnya (Gambar 6cd). Kisaran simpangan baku dari arus permukaan di lokasi inflow maupun outflow cenderung lebih tinggi dibanding dengan bagian dalam karena bagian permukaan banyak dipengaruhi oleh faktor eksternal yang mempengaruhi pergerakan arus sehingga variasi kecepatan arusnya lebih luas. Salah satu yang mempengaruhinya adalah perubahan arah angin (Stewart 2008). 

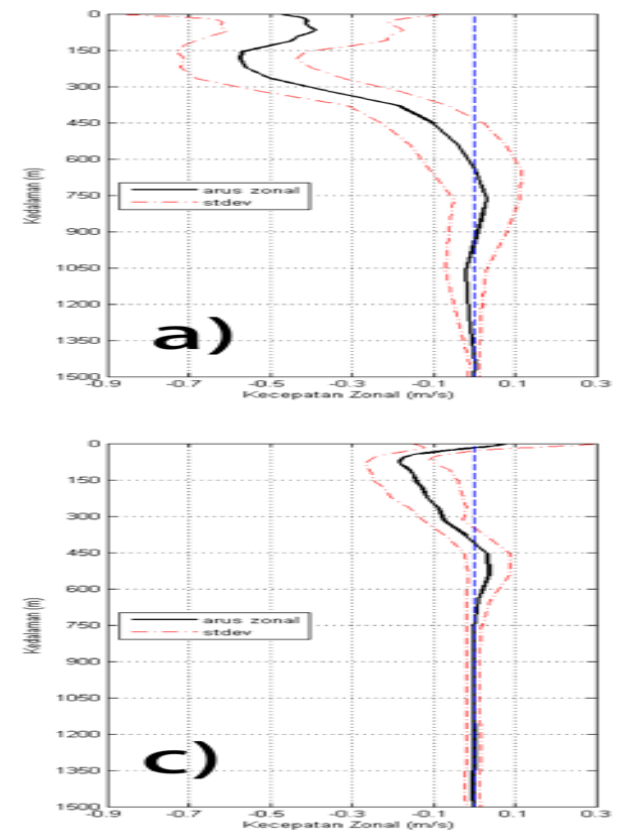
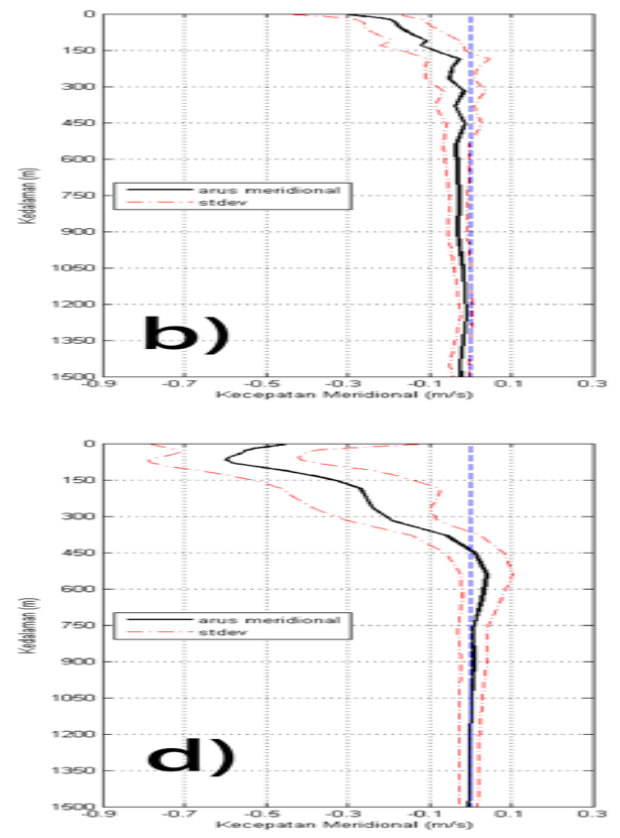

Gambar 6 Sebaran menegak komponen arus zonal dan arus meridional di lokasi inflow (a, b) dan outflow (c, d) dengan simpangan baku. Inset peta berupa kotak sampling berwarna hitam pada Gambar 2.

\section{Variabilitas Arlindo di Laut Sulawesi}

Komponen arus yang dominan di lokasi inflow Arlindo Sulawesi adalah arus zonal, sedangkan di lokasi outflow adalah komponen meridional (Gambar 6). Data deret-waktu komponen arus tersebut dianalisis lebih lanjut untuk melihat keeratan antara fluktuasi di inflow dan outflow pada tiga kedalaman yang berbeda, yaitu di lapisan tercampur $(12.5 \mathrm{~m})$, lapisan termoklin $(125 \mathrm{~m})$ dan lapisan bawah termoklin $(318 \mathrm{~m})$. Nilai simpangan baku maksimum untuk komponen arus di kedua lokasi tersebut terjadi di kedalaman tercampur (Tabel 1). Semakin bertambahnya kedalaman, nilai simpangan baku semakin rendah.

Tabel 1 Simpangan baku fluktuasi anomali arus pada tiga lapisan kedalaman

\begin{tabular}{|l|l|c|}
\hline \multirow{2}{*}{ Lapisan } & \multicolumn{1}{|c|}{ Komponen arus } & Simpangan baku (m/s) \\
\hline \multirow{2}{*}{ Tercampur } & Inflow (zonal) & 0.2610 \\
\cline { 2 - 3 } & Outflow (meridional) & 0.2326 \\
\hline \multirow{2}{*}{ Termoklin } & Inflow (zonal) & 0.2066 \\
\cline { 2 - 3 } & Outflow (meridional) & 0.2036 \\
\hline \multirow{2}{*}{ Bawah termoklin } & Inflow (zonal) & 0.1733 \\
\cline { 2 - 3 } & Outflow (meridional) & 0.1100 \\
\hline
\end{tabular}

Data deret-waktu fluktuasi arus di lokasi inflow dan outflow pada tiga lapisan kedalaman tersebut disajikan pada Gambar 7. Secara visual, fluktuasi data deret-waktu arus

tersebut terlihat didominasi oleh skala fluktuasi intra-musiman (periode 20-90 harian), dimana puncak amplitudo arus zonal di lokasi inflow berimpitan dengan puncak amplitudo arus meridional di lokasi outflow. Misalnya, fluktuasi arus di bulan November 2007, Juni 2008, Agustus 2009, Oktober 2010 dan 2011 (Gambar 7). Amplitudo fluktuasi kecepatan arus di lapisan tercampur dalam rentang sekitar -0.5 hingga $0.5 \mathrm{~m} \mathrm{~s}^{-1}$, lapisan 
termoklin sekitar -0.4 hingga $0.4 \mathrm{~m} \mathrm{~s}^{-1}$, dan lapisan bawah termoklin -0.2 hingga $0.3 \mathrm{~m} \mathrm{~s}^{-1}$ (Gambar 7). Semakin bertambahnya kedalaman, amplitudo kecepatan arusnya semakin kecil. Rentang nilai simpangan baku juga menunjukkan hal yang sama (Tabel 1). tercampur menunjukkan simpangan baku yang tinggi. Hal ini disebabkan oleh dinamika laut di dekat permukaan sangat sensitif terhadap pengaruh dinamika atmosfer, seperti fluktuasi gaya penggerak arus permukaan oleh gesekan angin (wind-stress).

Arus di bagian permukaan atau lapisan
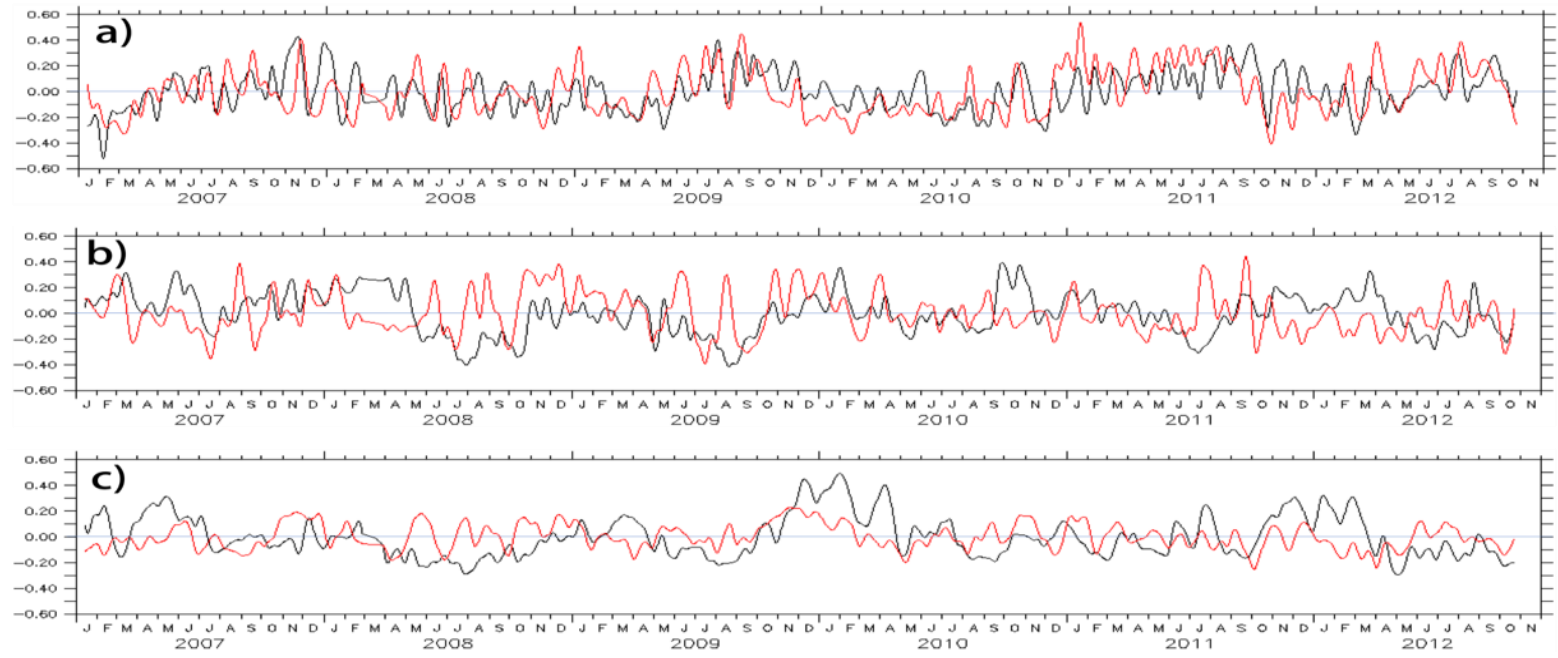

Gambar 7. Deret waktu komponen zonal di lokasi inflow (hitam) dan komponen meridional di lokasi outflow (merah) pada lapisan (a) tercampur, (b) termoklin, dan (c) bawah termoklin. Skala arus berbeda.

Spektrum densitas energi atau power spectral density (PSD) dengan selang kepercayaan $95 \%$ untuk komponen arus zonal dan meridional di tiga kedalaman berbeda disajikan pada Gambar 8-10. Dilapisan tercampur (Gambar 8) lokasi inflow puncak spektrum densitas energi signifikan ditemukan pada periode 21 , $35,42,57$, dan 81 harian (skala intramusiman). Di lokasi outflow variabilitas arus dominan terjadi pada periode $24,55,65,81$, 88 (skala intra-musiman). Lapisan termoklin (Gambar 9) di inflow terjadi puncak spektrum pada periode $22,54,70,82,88$ (skala intramusiman), sedangkan di outflow terjadi pada periode $24,82,88$, (skala intra-musiman). Pada lapisan bawah termoklin (Gambar 10) di inflow terjadi puncak spektrum pada periode 22, 42, 79, 86, 92, (skala intra-musiman), sedangkan di outflow terjadi pada periode 22, $42,79,89,92$, dan 95 (skala intra-musiman). Belum banyak diketahui penyebab dominansi variasi intra-musiman di Laut Sulawesi pada skala 20-90 harian (Gambar 8-10). Namun menurut penelitian Qiu et al. (1999) dan Matsumoto et al (2001) fluktuasi arus skala intra-musiman di wilayah ini berkaitan erat dengan aktivitas perambatan gelombang Rossby dari wilayah tepi barat ekuator Pasifik yang masuk di dekat pintu masuk bagian timurlaut Laut Sulawesi. Selain itu, dalam skala musiman, variasi musiman arus pada ketiga lapisan diperkirakan berkorelasi dengan fluktuasi penggerak angin Muson AsiaAustralia, yaitu pergerakan angin yang terjadi karena perbedaan tekanan udara antara Benua Asia dengan Australia akibat dari pergerakan semu Matahari. Puncak spektrum densitas energi signifikan pada skala tersebut menunjukkan fluktuasi kecepatan dan arah angin Muson mempengaruhi pola fluktuasi arus yang bergerak di Laut Sulawesi. Arah angin di Laut Sulawesi yang berada di Belahan Bumi Utara saat Muson Barat lebih condong bergerak dari timur laut dan saat Monsun Timur lebih condong bergerak dari barat daya. 


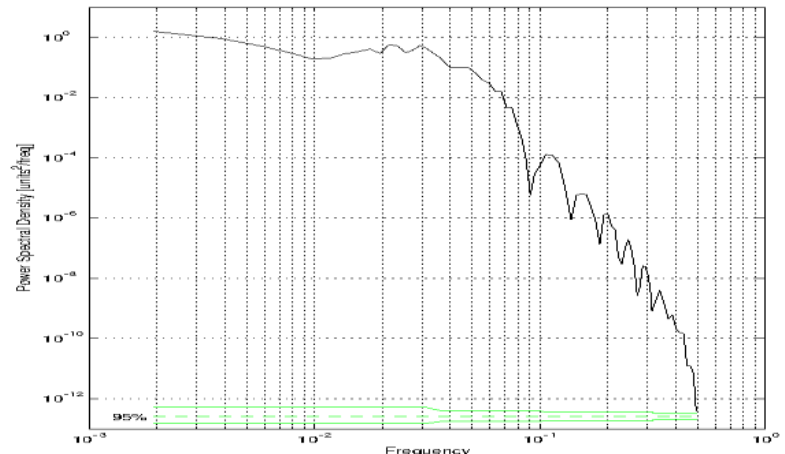

(a)

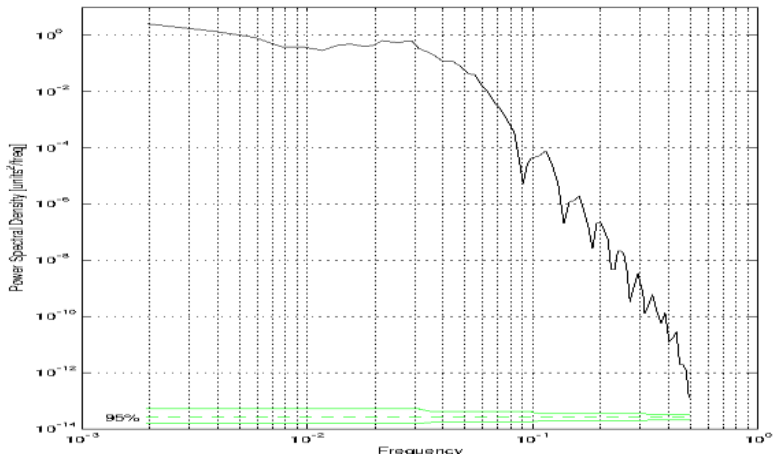

(b)

Gambar 8. Densitas Spektral Energi (PSD) untuk komponen arus zonal di lokasi inflow (gambar kiri) dan komponen arus meridional di lokasi outflow (gambar kanan). Satuan untuk frekuensi adalah siklus per hari (cycle per day, cpd). Garis hijau menunjukkan selang kepercayaan $95 \%$.

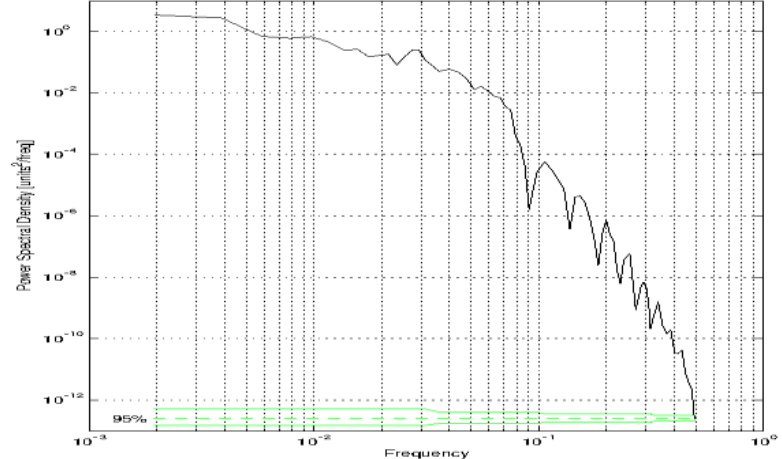

(a)

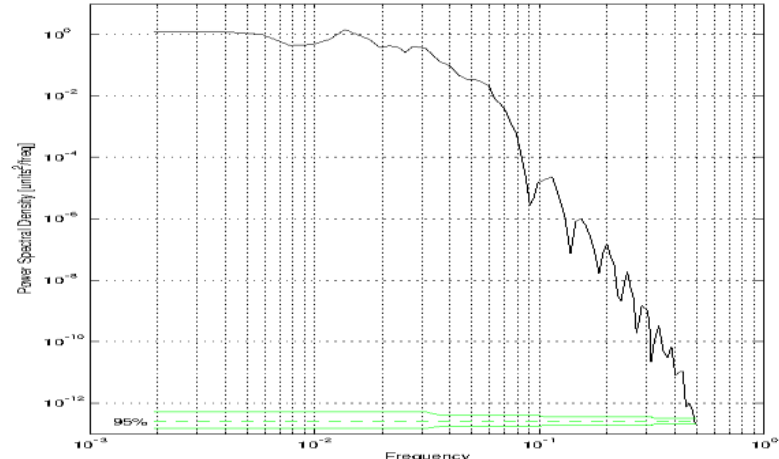

(b)

Gambar 9. Seperti pada Gambar 8, tetapi untuk PSD di kedalaman termoklin.

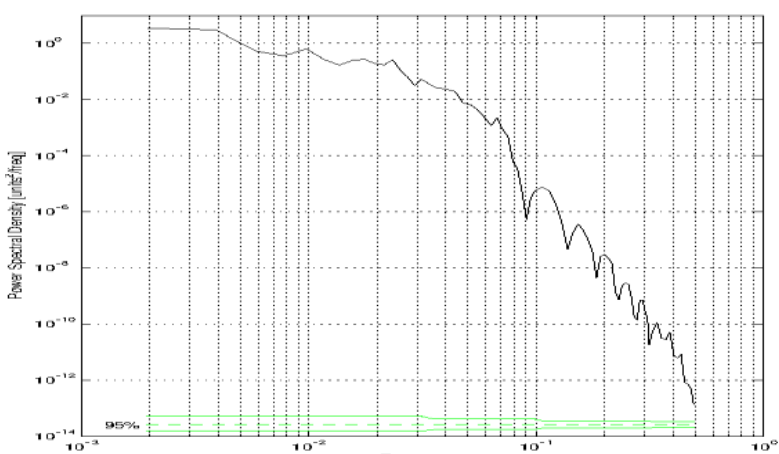

(a)

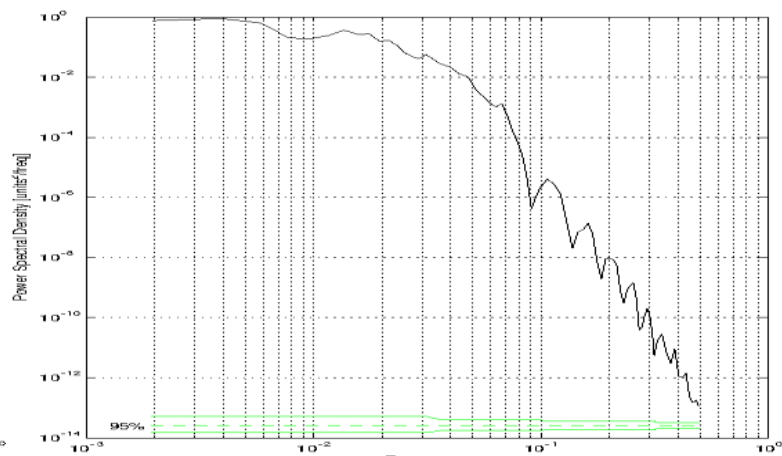

(b)

Gambar 10. Seperti pada Gambar 8, tetapi untuk PSD di kedalaman bawah-termoklin.

\section{Koherensi Fluktuasi Arlindo Sulawesi di Lokasi Inflow dan Outflow}

Analisis spektral silang (cross-power spectral density, cross-PSD) antara dua variabel data deret-waktu, yaitu data deret-waktu arus zonal di lokasi inflow Arlindo di timurlaut Laut Sulawesi dengan data deret-waktu arus meridional di lokasi outflow Arlindo di sisi utara Selat Makassar (lihat Gambar 7) bertujuan untuk menganalisis

bagaimana korelasi antara fluktuasi arus yang berada di inflow dengan yang di outflow. Dari hasil analisis PSD untuk masing-masing data deret-waktu arus terlihat bahwa puncak energi signifikan terjadi pada periodisitas skala intra-

JURNAL KELAUTAN NASIONAL, Vol. 11, No. 3, Desember 2016, Hal. 159-174 
musiman (Gambar 10). Korelasi dari kedua variabel data deret waktu tersebut dinyatakan dengan nilai koherensi, serta beda fase. Nilai koherensi mirip dengan nilai koefisien korelasi, yaitu nilai koherensi merupakan kuadrat korelasi antara dua variabel dari data deret-waktu (komponen arus zonal di inflow dan arus meridional di outflow) pada setiap frekuensi tertentu. Hasil analisis cross-PSD dengan segment length sebesar 512 data, di tiga level kedalaman berbeda terungkap bahwa nilai koherensi yang signifikan dari fluktuasi arus di kedua lokasi tersebut berada pada skala waktu intra-musiman yaitu antara 20 sampai 90 harian (Gambar 11a sampai 11c, dan Tabel 2).

Pada level kedalaman 15 m (Gambar 11a), nilai koherensi yang tertinggi (0.5473) terjadi pada periodisitas 34 harian dengan beda fase fluktuasi arus zonal di lokasi inflow mendahului dengan beda fase sekitar 0.0577 (atau sekitar 2 hari). Hal ini berarti, signal fluktuasi arus dengan periodisitas 34 harian merambat dari lokasi inflow Arlindo ke lokasi outflow Arlindo di sisi utara Selat Makassar sekitar dengan beda fase sekitar 2 hari. Nilai koherensi yang tinggi terjadi pada periodisitas antara 21 harian sampai 57 harian, dengan nilai koherensi kedua tertinggi sekitar 0.4265 terjadi pada periodisitas 21 harian (Tabel 2).
Pada level kedalaman termoklin $(130 \mathrm{~m})$, nilai koherensi tertinggi (sekitar 0.5826) terjadi pada periodisitas 34 harian (Gambar 11b). Periodisitas ini terlihat konsisten dengan fluktuasi signal arus di level kedalaman tercampur $(15 \mathrm{~m})$. Puncakpuncak nilai koherensi yang tinggi juga terjadi pada periodisitas 24 harian dengan nilai koherensi 0.2272 dan periode 64 harian dengan koherensi 0.168 (Tabel 2). Di level kedalaman bawah termoklin $(318 \mathrm{~m})$, nilai koherensi tertinggi (0.4644), terjadi pada periodisitas 39 harian. Puncak koherensi tinggi juga terjadi pada periodisitas 22 harian dan 57 harian (Tabel 2). Dari ketiga level kedalaman berbeda tersebut, tampak bahwa fluktuasi arus dengan periodisitas intra-musiman sekitar 34-39 harian menyajikan nilai koherensi yang paling tinggi dengan beda fase berkisar antara 0.0577 sampai 0.7805 . Hasil ini sangat konsisten dengan hasil penelitian sebelumnya (misalnya Qiu et al., 1999; Matsumoto et al., 2001), dimana fluktuasi arus dengan periode sekitar 34-39 harian di Laut Sulawesi berkaitan erat dengan kedatangan gelombang Rossby dari wilayah tepi barat ekuator Pasifik yang masuk ke Laut Sulawesi melalui pintu masuk Arlindo di bagian timurlaut Laut Sulawesi.

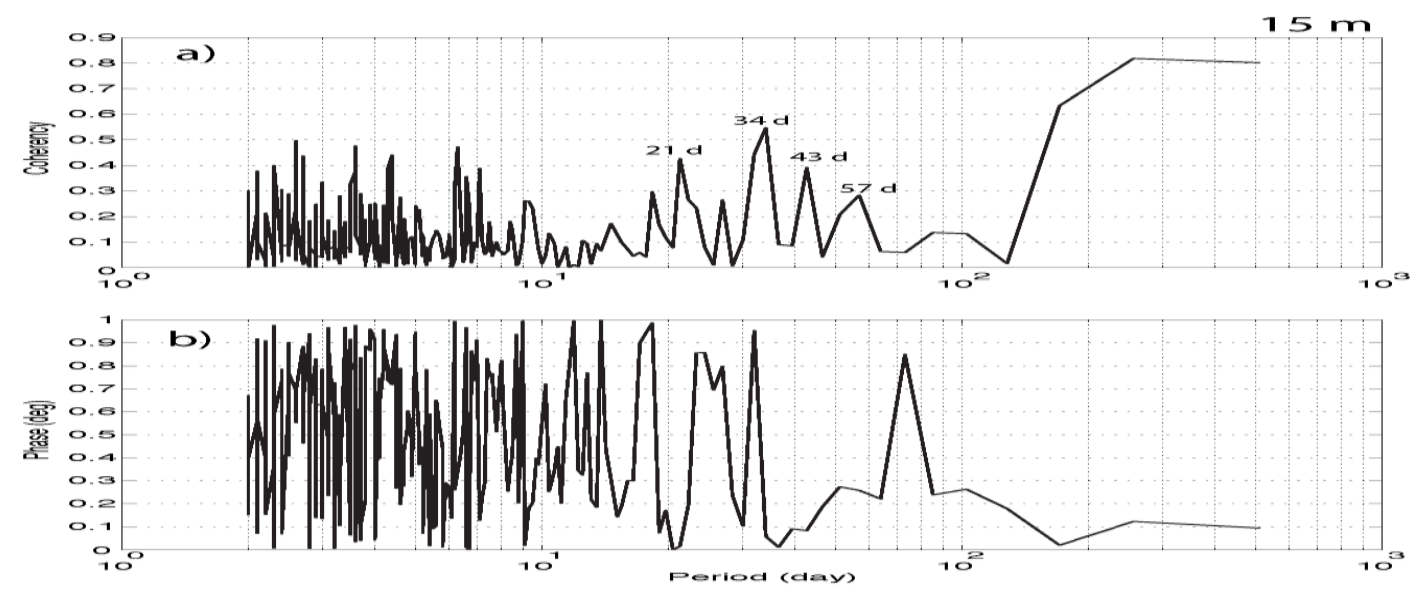

Gambar 11a. Hasil analisis PSD-silang (cross-PSD) antara data deret-waktu komponen arus zonal (timur-barat) di lokasi inflow dengan komponen arus meridional (utara-selatan) di lokasi outflow di kedalaman $15 \mathrm{~m}$. Nilai koherensi (a) dan fase (b). Satuan periode adalah harian. 

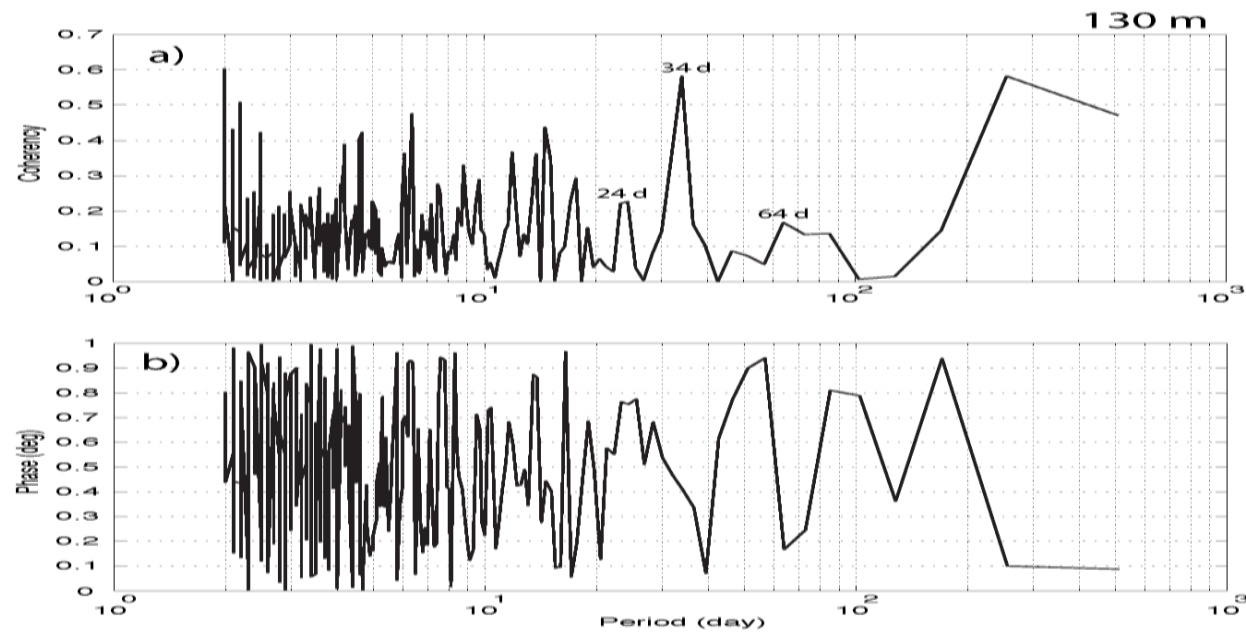

Gambar 11b. Seperti pada Gambar 11a, tetapi untuk data deret-waktu di kedalaman $130 \mathrm{~m}$.
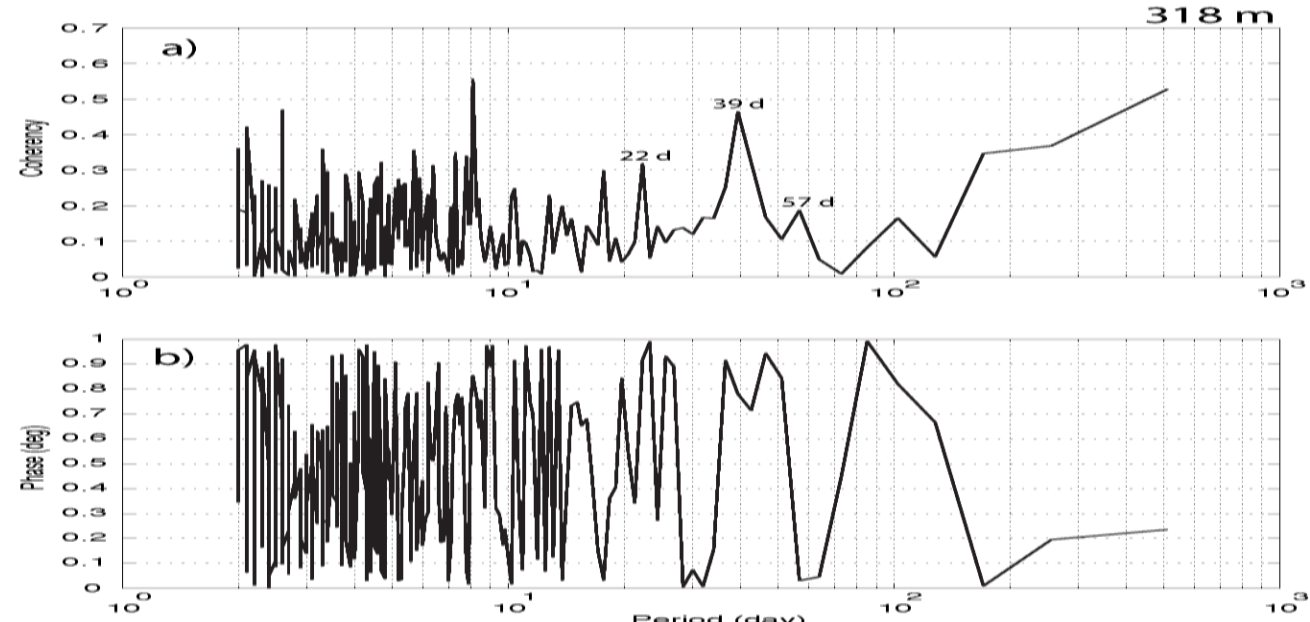

Gambar 11c. Seperti pada Gambar 11a, tetapi untuk data deret-waktu di kedalaman $318 \mathrm{~m}$.

Tabel 2 Nilai koherensi dan beda fase yang signifikan dari hasil analisis PSD-silang antara data deretwaktu komponen arus zonal di inflow dengan arus meridional di outflow pada 3 level kedalaman berbeda. Tanda asterik menunjukkan nilai koherensi paling tinggi. Satuan fase adalah fraksi dari lingkaran penuh.

\begin{tabular}{|c|c|c|c|}
\hline Level kedalaman & Periodisitas (harian) & Koherensi & Beda Fase \\
\hline & 21 & 0.4265 & 0.0153 \\
\hline $15 \mathrm{~m}$ & 34 & $0.5473^{*}$ & 0.0577 \\
\hline & 43 & 0.3920 & 0.2584 \\
\hline & 57 & 0.2838 & 0.2584 \\
\hline $130 \mathrm{~m}$ & 24 & 0.2272 & 0.754 \\
\hline & 34 & $0.5826^{*}$ & 0.409 \\
\hline & 64 & 0.168 & 0.1667 \\
\hline $318 \mathrm{~m}$ & 22 & 0.3188 & 0.9905 \\
\hline & 39 & $0.4644^{*}$ & 0.7805 \\
\hline & 57 & 0.1872 & 0.0312 \\
\hline
\end{tabular}


Di basin Laut Sulawesi, sebaran nilai koherensi dan beda fase pada kedalaman lapisan termoklin $(130 \mathrm{~m})$ dari hasil analisis cross-PSD antara data deret-waktu arus zonal di lokasi inflow Arlindo dengan data deretwaktu energi kinetik yang dihitung dari komponen arus zonal $(u)$ dan meridional $(v)$, menunjukkan nilai koherensi yang tinggi berada di sumbu arus utama Arlindo (Gambar 12). Sebaran nilai koherensi mengarah hampir ke arah barat dari lokasi inflow Arlindo, kemudian nilai koherensi tinggi berada di sepanjang tepi Kalimantan sampai bagian utara Selat Makassar. Nilai koherensi yang tinggi juga ditemukan secara di bagian tengah basin. Pola sebaran nilai koherensi tersebut dapat diartikan bahwa fluktuasi arus dengan periode 39 harian di sumbu utama Arlindo Sulawesi berkorelasi secara signifikan dengan fluktuasi arus di lokasi inflow Arlindo, dimana beda fase antara fluktuasi signal arus di inflow dengan di sumbu Arlindo berkisar antara 0.4 sampai 0.8, atau fluktuasi arus di lokasi inflow mendahului sekitar 15-31 hari terhadap fluktuai arus di sepanjang sumbu utama Arlindo (Gambar 12b).

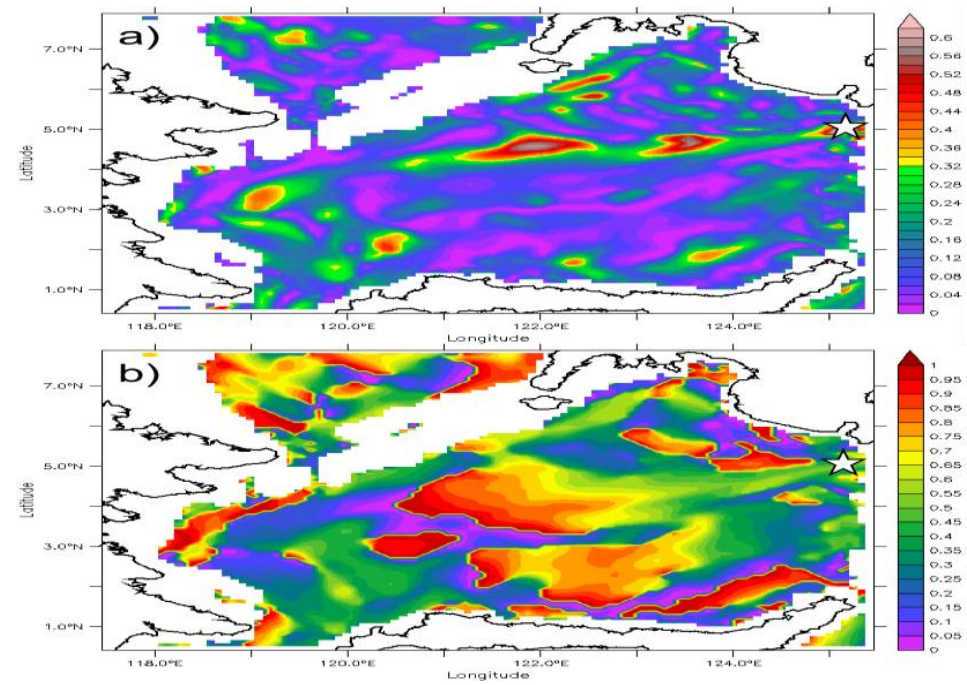

Gambar 12. Koherensi (a) dan beda fase (b) pada periode 39 harian dari analisis cross-PSD antara data deret-waktu komponen arus zonal di lokasi inflow Arlindo di bagian timurlaut Laut Sulawesi (tanda bintang) dengan energi kinetik (EK) dari arus zonal dan meridional pada kedalaman $130 \mathrm{~m}$ di basin laut Sulawesi.

\section{KESIMPULAN DAN SARAN}

Pola sirkulasi Arlindo di Laut Sulawesi dicirikan oleh tiga wilayah arus yang sangat unik, yaitu pertama adalah sumbu utama Arlindo dari lokasi inflow menuju outflow, kedua adalah resirkulasi atau pusaran arus yang searah jarum jam (clockwise) di tepi utara dari sumbu arus utama Arlindo, dan ketiga adalah pusaran arus yang berlawanan dengan arah jarum jam (anticlockwise) di bagian selatan dari sumbu arus utama Arlindo. Sumbu arus utama Arlindo dicirikan dengan vektor arus yang kuat yang mengalir ke arah barat dari lokasi inflow dan menyusuri tepi Kalimantan, dan masuk ke Selat Makassar, sehingga komponen arus dominan adalah arus zonal (timur-barat) dan meridional (utara-selatan) masing-masing di lokasi inflow dan outflow. Kedalaman arus maksimum dari Arlindo berada di kisaran kedalaman $150 \mathrm{~m}-250 \mathrm{~m}$.

Variabilitas arus di lokasi inflow berfluktuasi pada periodisitas dominan skala intra-musiman (20-90 harian) dengan puncak energi dalam periodisitas antara 21-64 harian. Koherensi yang signifikan antara fluktuasi arus di inflow dengan outflow dan juga dengan energi kinetik di basin Laut Sulawesi terjadi pada periodisitas 34-39 harian, yang diduga berkaitan dengan kedatangan gelombang Rossby dari sistem arus tepi barat ekuator Pasifik. Fluktuasi arus di lokasi inflow mendahului sekitar 15-31 hari dengan fluktuasi di sumbu utama Arlindo dan lokasi outflow di basin Sulawesi. 


\section{DAFTAR PUSTAKA}

Atmadipoera, A., Selfrida Horhoruw, M. Purba, Dwi Y. Nugroho. 2015. Variasi spasial dan variabilitas Arlindo Makassar. Jurnal Ilmu dan Teknologi Kelautan Tropis (ITKT), Vol 7 (1).

Bendat JS, Piersol AG. 2010. Random Data: Analysis and Measurement Procedures. Hoboken (US): Wiley.

[CLS] Collecte Localisation Satellites (FR). 2015. INDESO Product User Manual - Physical Model Outputs. Plouzané (FR): CLS.

Emery WJ, Thomson RE. 2014. Data Analysis Methods in Physical Oceanography. Waltham (US): Elsevier.

Fine RA, Lukas R, Bingham FM, Warner MJ, Gammon RH. 1994. The wetern equatorial Pacific: a watermass crossroads. J Geophys Res. 99:25,063-25,080.

Gordon AL. 1986. Interocean exchange of thermocline water. J Geophys Res. 91:5,0375,046 .

Gordon AL. 2005. Oceanography of the Indonesian seas and their throughflow. Oceanography. 18(4):14-27.

Gordon AL, Fine RA. 1996. Pathways of water between the Pasific and Indian oceans in the Indonesian Seas. Nature. 379(1):146149.doi:10.1038/379146a0.

Gordon AL, Sprintall J, Aken HMV, Susanto RD, Wijffels S, Molcard R, Ffield A, Pranowo W, Wirasantosa S. 2010. The Indonesian throughflow during 2004-2006 as observed by the INSTANT program. Dyn Atmos Oc. 50(2):1-14.doi:

10.1016/j.dynatmoce.2009.12.002.

Gordon AL, Susanto RD, Ffield A. 1999. Throughflow within Makassar Strait. Geophys Res Let. 26:3,3253,328.doi:10.1029/1999GL002340.

Madec G, Lévy C, Coward A, Ethé C, Iovino D, Clementi E, Bricaud C, Furner R. 2014.
NEMO Ocean Engine. Paris (FR): Institut Pierre Simon Laplace.

Masumoto, Y., T. Kagimoto, M. Yoshida, M. Fukuda, N. Hirose, T. Yamagata. 2001. Intraseasonal eddies in the Sulawesi Sea simulated in an Ocean General Circulation Model. Geophys Res Lett, 28 (8), 1631-1634.

McGregor S, Gupta AS, England MH. 2012. Constraining wind stress products with sea surface height observations and implications for Pacific Ocean sea level trend attribution. $J$ Clim. 25(23): 8164-8176.doi:10.1175/JCLI-D12-00105.1.

Qiu B, Mao M, Kashino Y. 1999. Intraseasonal Variability in the Indo-Pacific Throughflow and the Regions Surrounding the Indonesian Seas. J Phys Oc. 29: 1,599-1,618.

Sprintall J, Wijffels SE, Molcard R, Jaya I. 2009. Direct estimates of the Indonesian Throughflow entering the Indian Ocean: 20042006. J Geophys Res. 114:119.doi:10.1029/2008JC005257.

Stewart RH. 2008. Introduction to Physical Oceanography. Texas (US): Department of Oceanography, Texas A \& M University.

Susanto RD, Gordon AL, Sprintall J, Herunadi B. 2000. Intraseasonal Variability and Tides in Makassar Strait. Geophys Res Let. 27:1,4991,502 .

Timmermann A, McGregor S, Jin F-F. 2010. Wind effects on past and future regional sea level trends in the Southern Indo-Pacific. Ame Meteo Soc. 23(16): 4429-4437.doi: 10.1175/2010JCLI3519.1.

Tranchant B., G. Reffray, E. Greiner, D. Nugroho, R. Saint-agne, and R. Saint-agne, "Evaluation of an operational ocean model configuration at $1 / 12^{\circ}$ spatial resolution for the Indonesian seas Part I : ocean physics,” pp. 1-49, 2015.

Wyrtki K. 1961. Physical Oceanography of the Southeast Asian Waters. California (US): Scripps Institution of Oceanography, University of California. 